ARTIGO

\title{
O horizonte regional do Brasil e a construção da América do Sul
}

\author{
Brazil's regional horizon and the construction \\ of South America
}

LEANDRO FREITAS COUTO*

Rev. Bras. Polit. Int. 50 (1): 159-176 [2007]

Introdução ${ }^{1}$

Os países sul-americanos têm uma reconhecida vocação costeira. Desde os tempos em que foram descobertos para a História moderna do ocidente e introduzidos na vida internacional como colônias de potências européias, as suas principais conexões com o estrangeiro fluem por via marítima no sentido da Europa, em primeira instância, e da América do Norte, a partir do século XIX.

A dinâmica contemporânea das relações internacionais não conseguiu inverter totalmente essa tendência. Todavia, atualmente a América do Sul está muito mais presente na realidade da sociedade brasileira do que jamais esteve. As sociedades sul-americanas trilham, já há alguns anos, os caminhos que podem levá-las a uma maior aproximação.

Acima das sociedades, esse é também um movimento compartilhado pelos Estados, ou pelo menos por alguns deles. No caso brasileiro, a análise dos discursos e das articulaçóes endossadas pelos formuladores da política externa nacional demonstra que a América do Sul está cada vez mais presente como referência regional do país. A região passou a ser referência para, além do discurso e retórica diplomáticos, ações concretas que ganham gradativamente espaço e relevância na agenda nacional.

A escolha da regionalização adequada relaciona-se estreitamente com a construção de uma coesão interna que viabilize um reconhecimento mútuo de todos os países da região como partícipes de uma mesma unidade e a percepção desta unicidade por parte dos atores extra-regionais.

\footnotetext{
* Mestre em Relações Internacionais pela Universidade de Brasília - UnB (leandro.couto@gmail.com).

1 Este artigo é extensivamente baseado na dissertação de mestrado do autor, apresentada em 2006 ao programa de pós-graduação em Relaçôes Internacionais da Universidade de Brasília - UnB, intitulada O horizonte regional do Brasil e a Construção da América do Sul (1990 - 2005).
} 
Dentro dessa perspectiva, o presente artigo ancora-se numa linha argumentativa apoiada em quatro pontos principais. O primeiro deles é de que a articulação do conceito de América do Sul como componente da sua identidade internacional é um aspecto recente na história do Brasil. O segundo aspecto está em demonstrar que essa mudança na referência regional do país não se bastou no plano retórico, mas foi respaldado por uma série de ações que emprestam concretude às manifestações políticas, indo além da vertente econômica-comercial.

Esse movimento brasileiro insere-se num contexto no qual a América do Sul apresenta-se como um conceito ainda fluido. Os dados indicam que ainda não faz sentido falar de uma região sul-americana para além da sua geografia física. Assenta-se aí o terceiro aspecto basilar de toda a argumentação desenvolvida.

A constatação de que a América do Sul ainda é uma região a construir não invalida a iniciativa brasileira, pois se defende que os Estados têm um papel central na organização dos espaços que estimulem a formação do bloco regional. Nesse aspecto reflete-se o quarto e último ponto do trabalho, em que se insinua o tamanho dos obstáculos a transpor e a distância do caminho a percorrer para se alcançar a efetiva integração sul-americana.

\section{As referências regionais da identidade internacional do Brasil}

O Brasil, no curso de sua atuação internacional, utilizou-se de diferentes referências regionais que forneceram distintas plataformas para a articulação de seus movimentos no continente americano e no mundo. Essas referências regionais, que fazem parte da identidade internacional do país, remetem a conceitos diferentes, muitas vezes dissonantes, e refletem percepções distintas do arranjo regional e da inserção do Brasil nesse concerto.

A independência política de Portugal não significou ao Brasil a assunção imediata de sua vertente americana. A sua ligação com a África negra e suas relações com a Europa, principalmente com a ex-metrópole ibérica e com a Inglaterra, continuavam a lhe conferir uma vertente geo-econômica atlânticoafricana. ${ }^{2}$ Além disso, a forma de governo monárquica singularizava o país num continente que se identificava com a forma republicana.

Com o advento da república, o Brasil imediatamente precipitou-se em promover uma "americanização" da sua política externa. Associou automaticamente a sua identificação com o restante dos países republicanos da América a uma ruptura simbólica com as potências européias.

Principalmente a partir de Rio Branco, a introspecção de uma vertente americana indicou uma aproximação do Brasil com os Estados Unidos e com sua estratégia continental. Rio Branco apoiava o movimento pan-americanista

2 MAGNOLI, Demétrio. O corpo da pátria: Imaginação geográfica e política externa no Brasil. (1808-1912) São Paulo: Editora da Universidade Estadual Paulista: Moderna. 1997. 
advindo de Washington e tratava de lhe conferir um caráter instrumental para a estratégia de inserção regional do país. O Brasil enquadrava-se na moldura do pan-americanismo, e fazia disso parte do seu capital diplomático.

No entanto, ainda no século XIX, a história das Américas acentuaria o grau de bifurcação entre os caminhos percorridos por suas distintas partes. Principalmente, a economia distinguiria dois importantes conjuntos de países. Por um lado, destacar-se-ia uma América Anglo-saxã, incluindo Estados Unidos e Canadá, que conseguiu promover uma modernização da sua economia e, no caso particular do primeiro, tornar-se a potência econômica hegemônica do século XX. De outro lado, a América Latina, que manteria por mais algumas décadas o padrão de estruturação de sua economia nos moldes observados no período colonial. ${ }^{3}$

No decorrer do século XX, essa distinção foi se tornando cada vez mais clara. O termo "América" passou a ser suficiente para remeter aos Estados Unidos, e aos países ao sul do Rio Grande passou a bastar a generalização de "Latinos". Em 1948 foi criada a Comissão Econômica para a América Latina - CEPAL (somente em 1984 agregaria "Caribe" no nome), o que significava um reconhecimento institucional à região.

No período pós-Segunda Guerra Mundial, e mais intensamente com a détente entre as duas superpotências que protagonizavam a Guerra Fria, na década de 60, a América Latina ganhou espaço como ator internacional, num momento em que surgiam novas forças políticas no cenário mundial. O realce de interesses e objetivos comuns, em meio à diversidade que sempre marcou os países da região, incitou uma configuração regional que se contrapunha à América do Norte e aos Estados Unidos em particular.

Conquanto as disparidades criassem empecilhos à consecução de projetos integracionistas capazes de abranger todos os países da região, a América Latina converteu-se na referência regional da diplomacia brasileira. Mesmo que inconstante, substituiu a vertente "pan" ou interamericana da identidade internacional do Brasil.

Na década de 1980, a referência latino-americana perdeu força com a crise financeira que assolou a região e, particularmente, com as mudanças impostas pela queda do império soviético. O fim da Guerra Fria indicou a queda do bipolarismo político-militar. Os Estados Unidos contavam com uma poderosa máquina de guerra advinda da corrida armamentista do período anterior que os colocava numa posição de incontestável liderança mundial. No campo econômico, porém, a posição norte-americana era questionada por outros países, como a Alemanha e o Japão, o que gerava uma diferença entre a concentração do poder político e do poder econômico mundial.

3 SINGER, Paul. América do Sul: 2006 - da Geografia à História. Artigo apresentado por ocasião do Seminário América do Sul: 2006, realizado no Rio de Janeiro, 15 de agosto de 1997. Texto disponível em http://www2. mre.gov.br/ipri/Papers/AmericadoSul/Artigo17.doc. Último acesso: 20.7.2006. 
Do lado soviético, ocorreu um processo de "atomização". Novos países surgiam alimentados por um nacionalismo até então sufocado por Moscou e ingressavam, gradativamente, na zona de influência do bloco europeu. Dallanegra ${ }^{4}$ indica que, diante desse processo, aos Estados Unidos restou a iniciativa de formar arranjos regionais para garantir seu espaço estratégico e tentar resolver os problemas de sua balança comercial.

Nesse contexto, surge o North America Free Trade Area - NAFTA, que anexou a economia mexicana à norte-americana. Da mesma forma, os EUA já exerciam um forte poder de atração nos países centro-americanos e caribenhos. Assim, a América Latina foi perdendo funcionalidade como elemento identitário dos países da região.

O processo de aproximação entre Brasil e Argentina, por sua vez, abria caminho para a formação de um arranjo sub-regional de integração, culminando com a criação do Mercado Comum do Sul - Mercosul. Foi, então, no novo bloco comercial que o Brasil buscou a nova referência regional da sua identidade internacional. O dinamismo inicial do Mercado Comum reforçava essa idéia, mas o seu rápido declínio indicava a necessidade de ampliação do horizonte regional que abrigasse um Brasil que era, em si mesmo, maior que o Mercosul.

Com isso, a América do Sul, que sempre constou das considerações geopolíticas brasileiras, passou a representar a plataforma regional que referencia a estratégia de inserção internacional do Brasil. Algumas luzes foram lançadas nessa direção em meados da década de 1990, mas é no início do século XXI que essa tendência parece se consolidar.

A distância temporal ainda não permite afirmar se essa referência trará resultados práticos em termos da integração e do desenvolvimento dos países da região. O que é passível de constatação é que ela representa um ponto de inflexão quanto ao período anterior.

$\mathrm{O}$ que se pôde perceber é que, de fato, a referência regional da identidade brasileira, a circunstância do eu diplomático brasileiro, sofreu um movimento de retração com o passar dos anos. Se se considera que a identidade internacional de um país é indicada com o conjunto de predicados que respondem a pergunta "quem sois?", a resposta a essa pergunta mudou ao longo do tempo. O Brasil já foi americano, latino-americano e, atualmente, é sul-americano.

De fato, a mudança da referência regional da política externa brasileira, longe de implicar qualquer incoerência na sua atuação internacional, representa a busca por uma plataforma mais concreta através da qual o país consiga inserir-se mais ativamente na política internacional. A proposta de inserção internacional do Brasil lastreada pela sua identificação sul-americana implica, assim, a execução de ações paralelas e complementares de afirmação do conceito de América do Sul,

4 DALlANEGRA PEDRAZA, Luis. Relaciones Políticas entre Estados Unidos y América Latina: ¿Predominio monroista o unidad americana? Buenos Aires: Edic. del Autor, 1994. 
que permanece pouco explorado, e ainda muito abstrato para os atores da vida internacional.

A absorção de uma "sul-americanidade" na identidade internacional do Brasil significou, portanto, a construção ou mesmo a moldagem de ferramentas ou iniciativas que fortalecessem essa nova dimensão.

\section{As ferramentas de afirmação da sul-americanidade brasileira}

Ao optar por reforçar o componente sul-americano de sua identidade internacional, o Brasil lançou mão de uma série de iniciativas em sua política externa e de instrumentos calcados nas suas políticas setoriais com um foco estritamente sulamericano. Essas iniciativas podem ser consideradas tanto reflexos da introspecção de sua sul-americanidade quanto elementos para o seu fortalecimento.

Sendo causa ou conseqüência dessa nova fase, esses instrumentos fazem parte de um processo que parece, se não pela sua maturidade, mas por sua concretude, bastante marcado nos movimentos regionais brasileiros. São ações concretas que tornam o conceito de América do Sul nítido e inequívoco, instrumentalizando a política exterior do Brasil baseada na percepção dos seus contornos regionais.

A diversidade de açôes voltadas para a região indica que a integração sulamericana extrapola a estratégia econômico-comercial. No rol de iniciativas levadas a cabo pelo Brasil, direcionadas a todo o bloco sul-americano, as açóes no campo econômico, lato sensu, continuam tendo papel fundamental, mas atividades nas áreas cultural, educacional e científica e tecnológica também têm lugar importante na estratégia brasileira para a região.

Pretende-se destacar as iniciativas brasileiras que, a partir de meados da década de 1990, e mais fortemente no final do século XXI, na medida em que o Brasil vai se apropriando do componente sul-americano de sua identidade internacional, visam a firmar a América do Sul como espaço preferencial de sua atuação regional. Mais do que fortalecer sua já destacada posição dentro do continente sul-americano, o Brasil almeja consolidar o espaço geográfico também como um espaço geoeconômico e político.

A proposta para a criação de uma área de livre comércio que abrangesse toda a região sul-americana foi a primeira iniciativa brasileira que dava contornos econômico e comercial a um espaço já bem demarcado pela geografia. Apresentada pelo Presidente Itamar Franco na VII Reunião de Cúpula do Grupo do Rio, realizada em 1993, em Santiago, refletia as preocupaçôes brasileiras quanto à sua inserção internacional num momento em que ocorriam densas negociações comerciais e se formavam novas zonas regionais que anunciavam um rearranjo no modus operandi do comércio internacional.

Como aponta Moniz Bandeira, o perfil do comércio do Brasil com os países do Mercosul assemelhava-se ao intercâmbio entre países industrializados e os países em desenvolvimento, ou seja, exportação de alto valor agregado e compra 
de commodities. ${ }^{5}$ O comércio do Brasil com os demais países da América do Sul apresenta características semelhantes, donde se tem que, na década de 1990, cerca de $80 \%$ das exportaçōes brasileiras para a regiāo constituíam-se de artigos manufaturados. ${ }^{6}$

A ALCSA trazia em si um caráter de complementaridade com o Mercosul. Respondia aos anseios brasileiros de alargar a abrangência do mercado comum do cone sul para todo o continente sul-americano. Cabe ressaltar, porém, que os países caribenhos da América do Sul não estavam incluídos na proposta da ALCSA. Nem a ALADI, que conta com a presença de México e Cuba, nem a Comunidade Andina abarcavam a Guiana e o Suriname, que estariam excluídos do novo arranjo econômico, apesar de geograficamente serem sul-americanos. Foi somente com a iniciativa do Presidente Fernando Henrique Cardoso de reunir todos os presidentes sul-americanos em Brasília, no ano 2000, que esse fato seria corrigido.

Ainda no decorrer da década de 1990, a construção de um bloco sulamericano continuou no horizonte da política externa brasileira, mas deixou de ser o seu foco principal. A estratégia adotada para a construção de uma zona regional de livre comércio a partir da agregação de países ao Mercosul mostrouse lenta. As crises financeiras que afetaram o globo na última década do século $\mathrm{XX}$ abalaram especialmente as economias menos desenvolvidas e provocaram divergências internas ao próprio Mercado Comum do Sul. Foi preciso criar, em 1999, um Grupo de Trabalho sobre Coordenação de Políticas Macroeconômicas para que os membros do Mercosul pudessem tentar elevar os níveis de comércio intra-bloco, abalados pelas crises.

No entanto, isso não foi impeditivo para a conclusão de acordos do Mercosul com a Bolívia e com o Chile em 1996 e da assinatura de um acordoquadro entre Mercosul e Comunidade Andina de Nações (CAN) em 1998. Nessa linha, Fernando Henrique Cardoso, na reunião de trabalho dos chefes de Estado e de governo do Mercosul e Chile e da União Européia realizada em 1999, no Rio de Janeiro, enfatizou os avanços alcançados nas negociaçóes com os dois países, posicionando-os como parte do processo de construção do espaço sulamericano. $^{7}$

Já em 2000, o Brasil convidou os chefes de Estado e de governo dos 11 países sul-americanos para uma reunião de cúpula em Brasília. Em nota oficial de março daquele ano, o Itamaraty anunciava a reunião e já adiantava a sugestão

5 BANDEIRA, Luiz Alberto Moniz - Brasil, Argentina e Estados Unidos - Conflito e Integração na América do Sul. (Da tríplice aliança ao Mercosul 1870-2003) Rio de Janeiro: Revan: 2a edição. 2003. p. 499

6 SERRA, José. ALCA, o Mercosul e a Abertura Externa Brasileira. In Política Externa, vol. 7. no 1 - junhojulho-agosto 1998. Disponível em http://www2.mre.gov.br/ipri/Papers/AmericadoSul/Artigo11.doc Acessado em 17.1.2006

7 Discurso do Presidente Fernando Henrique Cardoso, na abertura da reunião de trabalho dos chefes de Estado e de governo do Mercosul e Chile e da União Européia, 28 de junho de 1999, no Rio de Janeiro, Folha de São Paulo, 29.6.1999. 
de quatro temas que seriam tratados na reunião: Democracia; Comércio; Infraestrutura de integração; e Drogas e delitos conexos. ${ }^{8}$

Ampliando o escopo para outros temas além do comercial, fugia-se do imbróglio que assolava as relações regionais e retomava-se a idéia de construção de um bloco sul-americano. Na mesma nota, o governo brasileiro afirmava que, a partir da experiência acumulada com as iniciativas integracionistas já existentes na região, se esperava gerar "as condições necessárias para a organização do espaço sul-americano de acordo com as características, necessidades e potencialidades que singularizam nossa região"'.

A estratégia voltava a ser a construção do novo "espaço sul-americano" a partir dos blocos já existentes. Por isso, ganhava importância o fato de a reunião ter focado em temas específicos, para além da esfera comercial. A tentativa de construção do bloco sul-americano não poderia incorrer no mesmo erro do Mercosul de se assentar apenas no comércio. Os países da região estavam dispostos a discutir também a questão democrática no subcontinente, planejar conjuntamente integração das infra-estruturas, combater o tráfico de ilícitos e crimes conexos e discutir formas de incentivar a produção de ciência e tecnologia na região como meio para galgar uma posição mais ativa no sistema produtivo mundial.

De todos, porém, o tema da integração das infra-estruturas da América do Sul foi o que recebeu mais atenção na reunião de 2000, ocasião na qual foi lançada a iniciativa para a Integração da Infra-estrutura Regional Sul-Americana - IIRSA, e foi o cerne também das reuniōes de presidentes subseqüentes. A II ${ }^{a}$ Reunião de Presidentes da América do Sul, realizada em Guaiaquil, Equador, em julho de 2002, elevou as discussões sobre a integração da infra-estrutura ao centro da agenda. Segundo comunicado do Itamaraty à imprensa, o próprio presidente Cardoso teria sublinhado a importância que gostaria que fosse concedida à questão na reunião ${ }^{10}$. O fracasso da reunião do Equador poderia representar o fracasso da iniciativa brasileira de formação do espaço sul-americano, e por isso o Brasil considerava essencial que a reunião focasse os avanços alcançados a partir da reunião de Brasília, revelando a continuidade e a conseqüência das iniciativas lançadas naquela ocasião. Como resultado, parte substantiva do "Consenso de Guaiaquil sobre Integração, Segurança e Infra-Estrutura para o Desenvolvimento” versa sobre a infra-estrutura regional e sobre a IIRSA em particular.

Dois anos depois seria realizada a III Reunião de Presidentes da América do Sul, dessa vez em Cuzco, no Peru. Essa reunião representou um avanço com relação às reuniōes anteriores, sem implicar descontinuidade. $\mathrm{Na}$ ocasiāo, foi lançada a Comunidade Sul-Americana de Nações - CASA, através da "Declaração de

8 Nota no 105, de 23.3.2000. Disponível em http://www.mre.gov.br/portugues/imprensa/nota_detalhe. asp?ID_RELEASE=643 Acessado em 6.2.2006.

9 Idem.

10 Comunicado Oficial à Imprensa, Disponível em http://www.mre.gov.br/portugues/imprensa/nota_detalhe. asp?ID_RELEASE=1352 Acessado em 22.7.2006. 
Cuzco sobre a Comunidade Sul-americana de Nações", e assinada a "Declaração de Ayacucho", que reafirmava o respaldo da IIRSA e apresentava uma lista de 31 projetos prioritários de infra-estrutura a serem implementados até 2010, resultante dos trabalhos dessa iniciativa.

João Mendes Pereira destaca que a idéia de criação de uma instância que institucionalizasse o diálogo político sul-americano começou a ganhar força a partir dos freqüentes encontros entre os mandatários dos países da região nos anos de 2003 e 2004 . No entanto, Pereira ressalta que foi necessário "desgastante e prolongado esforço negociador", principalmente frente à Colômbia e ao Uruguai, e em menor escala, com o Chile, para formalizar a constituição da Comunidade Sul-americana de Nações, em Cuzco, mostrando a existência de diferentes percepções entre os países sobre a melhor estratégia para a implementação da integração no continente ${ }^{11}$.

Com a instituição da Comunidade Sul-americana de Nações, as reuniōes de presidentes da América do Sul seriam substituídas pelas Reuniōes de Chefes de Estado e de Chanceleres da Comunidade Sul-americana de Nações. A iniciativa lançada em 2000 por Fernando Henrique alcançava, quatro anos depois, resultados concretos no sentido da "formação do espaço sul-americano": a institucionalização política da região, apoiada por projetos concretos de interconexão física capazes de impulsionar uma maior interdependência regional.

A I Reunião dos Presidentes e Chefes de Governo dos países da Comunidade Sul-americana de Nações realizou-se em Brasília, em setembro de 2005. Nela, estabeleceu-se uma agenda prioritária para as atividades da entidade, coerente com o que vinha sendo discutido no fórum anterior. Foram oito os temas selecionados: diálogo político; integração física; meio ambiente; integração energética; mecanismos financeiros sul-americanos; assimetrias; promoção da coesão social, da inclusão social e da justiça social; telecomunicações. ${ }^{12}$

Ademais, os presidentes aprovaram um programa de ação, com indicações de atividades que dariam conseqüência aos temas prioritários. Previu-se a constituição de um foro sul-americano de consulta e coordenação política, formado a partir de mecanismos já existentes no Mercosul e na Comunidade Andina, agregando representantes da Guiana e Suriname. A programação de atividades indicava também ações para eliminar a exigência de vistos para a circulação de cidadãos entre os países, erradicar a febre aftosa, dengue e malária, estimular a promoção de comércio e investimentos intra-bloco, integrar a infra-estrutura, além de estimular a integração turística e cultural, entre outros. ${ }^{13}$

11 PEREIRA, João Mendes. A iniciativa para a Integração da Infra-estrutura Regional da América do Sul-IIRSA como instrumento da politica brasileira para integração da América do Sul. Tese apresentada no XLVIII Curso de Altos Estudo do Instituto Rio Branco, 2005.

12 BRASIL. Ministério das Relações Exteriores/Fundação Alexandre de Gusmão. Comunidade Sul-Americana de Naçôes: documentos , 2005.

13 Idem. 
Notadamente, a integração da infra-estrutura regional vem ganhando gradativamente cada vez mais espaço nas discussões acerca das estratégias para a consolidação da integração sul-americana. Com o advento do Governo Lula, a estratégia de integração da infra-estrutura ultrapassa a IIRSA.

Em agosto de 2003, o BNDES e a CAF promoveram o Primeiro Seminário Internacional de Co-financiamento BNDES/CAF: Prospecção de Projetos de Integração Sul-americana. O seminário objetivava identificar projetos de infraestrutura a serem financiados pelos dois organismos nos doze países da América do Sul, a despeito do processo em curso na IIRSA. Esperava-se, com isso, inserir o BNDES no processo de integração física sul-americana. Inclusive, criou-se no Banco um departamento específico, dentro da área de comércio exterior, para tratar das questôes relativas à integração sul-americana.

Mais recentemente, a questão energética começou a ganhar mais espaço na agenda política regional, ultrapassando também os trabalhos da iniciativa IIRSA. A suspensão unilateral das remessas argentinas de gás ao Chile e ao Brasil - termelétrica de Uruguaina, em 2004, a instabilidade política atravessada pela Bolívia nos últimos anos e a postura venezuelana frente à questão trouxeram à baila projetos como o Anel Gasífero Sul-americano, que levaria gás do Peru ao Chile e Argentina, com ligações com Paraguai e Brasil, e o Gasoduto do Sur, proposta de Hugo Chávez para levar o gás da bacia do Orinoco ao Brasil e Argentina, principalmente.

Além da integração da infra-estrutura, as questões comerciais receberam atenção especial. Em maio de 2003, o Brasil lançou um novo programa de estímulo ao comércio na América do Sul, o Programa de Substituição Competitiva de Importações - PSCI. A iniciativa fundamentava-se na premissa de que o estímulo às importações da região, que substituíssem, competitivamente, importações procedentes de outras partes do mundo, contribuiria para o crescimento econômico dos países vizinhos e, conseqüentemente, geraria um círculo virtuoso de aprofundamento da integração. Dessa forma, amenizariam os déficits estruturais que os países vizinhos têm nas suas relações comerciais com o Brasil.

E, não só o déficit comercial dos países da região com o Brasil era preocupante, mas também a participação da América do Sul nas importaçōes brasileiras vinha diminuindo sensivelmente. Com o fluxo comercial desbalanceado em favor do Brasil, tentava-se incentivar, através do programa, os investimentos brasileiros na região e impulsionar a importações advindas da América do Sul.

Também como conseqüência da I Reunião de Presidentes da América do Sul, na qual o Brasil propôs o estabelecimento de um Fundo Sul-americano de estímulo às atividades de cooperação científica e tecnológica na região, o Ministério da Ciência e Tecnologia do Brasil, sob a gestão de Ronaldo Sardenberg, criou, por meio da portaria no 872, de 20 de dezembro de 2001, o Prosul.

O programa objetiva apoiar atividades de cooperação em ciência e tecnologia que contribuam para o desenvolvimento científico e tecnológico dos países da 
região. Isso inclui atividades de prospecção, identificação e formulação conjunta de iniciativas que promovam o intercâmbio da comunidade científica regional.

$\mathrm{Na}$ área de segurança, a regiāo andina converteu-se na área mais instável da América do Sul e, portanto, principal alvo das preocupações geopolíticas do Brasil. No conflito Peru-Equador, em 1997, o Brasil atuou ativamente como mediador nas negociações para solucionar o impasse. Seguiu também com distância cautelosa os desdobramentos da atuação dos Estados Unidos no combate às FARC na Colômbia.

Mais recentemente, já com o Governo Lula, o Brasil liderou o Grupo de Amigos da Venezuela, que teve papel ativo na distensão dos ânimos que alimentavam o conflito interno naquele país. $\mathrm{Na}$ mesma linha, o Brasil se fez presente e atuou, ao lado da Argentina, na resolução das crises recorrentes na Bolívia, do mesmo modo que adquiriu um papel de destaque na crise equatoriana que levou à deposição do cargo o então presidente Lucio Gutierrez, em 2005, tendo sido criticado pela sociedade local pelo auxílio prestado na retirada do expresidente do país e pela concessão de asilo político a este.

Nessa linha de atuação, com a sul-americanização do Brasil e da sua política externa, o Brasil tem respondido ativamente aos novos desafios de segurança. A rede de relações que vem mantendo na América do Sul alterou significativamente a qualidade da presença brasileira na regiāo, inclusive na área de segurança, ainda que o país continue a dispor de pouca capacidade de ser o fiador de uma ordem regional. ${ }^{14}$

Ademais, as áreas de educação e cultura também vêm sendo exploradas no seu potencial integracionista. No Brasil, promulgou-se, em 5 de agosto de 2005, a Lei $n^{\circ} 11.161 / 2005$, que adotou o espanhol como segunda língua e regulamentou o ensino de espanhol nas escolas brasileiras. Além disso, os presidentes acordaram em desenvolver conjuntamente projetos de erradicação do analfabetismo e estabelecer um programa de bolsas e formação técnica. ${ }^{15}$

Além da intenção de se criar uma agenda cultural sul-americana, expressa no programa de ação da CASA, o Brasil também tomou iniciativas para a promoção da integração cultural sul-americana. O Canal Integración, voltado para a América do Sul, com conteúdo cultural e informativo de várias emissoras públicas e organizações sem fins lucrativos, já transmite programas da TV Brasil, que resultou da cooperação entre os poderes executivos, legislativo e judiciário brasileiro. Irmã da Telesur venezuelana, essas iniciativas objetivam divulgar não só uma "visão sul-americana" dos acontecimentos internacionais e regionais, mas principalmente a diversidade das manifestaçôes culturais da região.

14 SENNES, Ricardo, ONUKI, Janaina \& AMÂNCIO, Jorge de Oliveira. La política exterior brasileña y la seguridad hemisférica. Revista Fuerzas Armadas y Sociedad. Año 18, no 3-4. p. 3-26, 2004. Chile. Disponível em http://www.fasoc.cl/files/articulo/ART41f69fdb82038.pdf Acessado em 27.7.2006.

15 Decisão sobre propostas apresentadas durante o diálogo presidencial. Comunidade Sul-Americana de Naçōes: Documentos, 2005. Op. cit. 
Obviamente, o levantamento feito até aqui não é exaustivo. Pretende revelar, contudo, a dimensão e a articulação das iniciativas sul-americanas do Brasil que, todavia, não excluem outras vinculações internacionais, mas ajudam a consolidar a América do Sul como referência regional da política externa brasileira. Em realidade, constituem uma série de iniciativas que, se tomadas isoladamente, podem não revelar muito em si mesmas. Porém, no seu conjunto, indicam uma nova orientação estratégica que fortalece os contornos regionais da identidade internacional do Brasil.

\section{Que América do Sul?}

A América do Sul é um continente fortemente heterogêneo. As desigualdades entre os países se expressam em diversos setores e com várias facetas. Muito além das características geográficas e populacionais, a situação econômica e social dos doze países revela condições díspares de desenvolvimento e de capacidade de inserção no cenário internacional ou mesmo regional.

Essa heterogeneidade expressa-se em termos da constituição dos fluxos intra-regionais, que se têm estabelecido com intensos desequilíbrios. Isso impacta sobremaneira na afirmação da América do Sul enquanto região articulada e integrada solidariamente. A seguir, serão apresentados alguns indicadores que traduzem as afirmaçôes acima e sinalizam a dificuldade de perceber uma unidade no continente sul-americano que ultrapasse o seu sentido geofísico.

A análise da participação de cada país no Produto Interno Bruto da região é reveladora das disparidades intra-regionais. Segundo dados da CEPAL, em 2004 o Brasil detinha um PIB de US\$ 655,35 bilhōes, o que representava cerca de $48,1 \%$ do PIB total da América do Sul - que era de aproximadamente US\$ $1.176,60$ bilhões. A Argentina participava com 21,09\% do total, cerca de US\$ 287,40 bilhões. A Venezuela, sobre uma plataforma riquíssima em petróleo, era responsável por 8,81\%, ou US\$120,07 bilhões. Esses três países respondiam, em 2004, por 78\% de tudo que foi produzido na região. Aos demais 9 países, restavam pouco mais de $20 \%$. Ainda, ao agregar a esse grupo Chile, Colômbia e Peru, chega-se a 6 países, $50 \%$ dos que conformam a região, respondendo por cerca de $94 \%$ da produção regional.

As desigualdades assumem outra feição ao se observar a evolução e o retrato atual do PIB per capita nos países sul-americanos. Nessa seara, em 2004, a Argentina, o Uruguai, o Chile e a Venezuela superavam o Brasil. A Guiana destacava-se em último lugar entre os doze sul-americanos, o único país a ter um PIB per capita menor do que US\$ 1000 anuais. Imediatamente acima apareciam Bolívia, Paraguai, Equador e Suriname, os quatro com PIB anual por habitante entre U\$ 1000 e US\$ 2000. Em posições intermediárias restavam a Colômbia, com US\$ 2074 por habitante/ano, e o Peru, com US\$ 2209. 
A tornar mais complexo o retrato sul-americano, a situação das desigualdades na distribuição interna da riqueza em cada um dos países apresenta outra faceta da realidade sul-americana. Segundo dados do Banco Mundial de 2005, o Brasil detinha naquela o pior Índice de Gini dos países sul-americanos $(0,593)$, enquanto o Equador ocupava o primeiro posto $(0,437)$, seguido por Uruguai $(0,446)$, Bolívia $(0,447)$, Venezuela $(0,491)$ e Peru $(0,498)$. Em seguida, seguem Argentina $(0,522)$, Chile $(0,571)$, Colômbia $(0,576)$ e Paraguai $(0,578)$ (não foram encontrados dados para Guiana e Suriname).

A Guiana, o país mais pobre da América do Sul, tanto em termos absolutos como por habitante, é, inversamente, o país que mais investe em educação em relação ao PIB, 8,4\%. A Bolívia, também um dos países mais pobres da região, vem em seguida, ao lado da Colômbia, ambos os países com investimentos em educação na ordem de 5,2\% do PIB. Segue a lista com Paraguai, 4,4\%, Brasil e Chile, 4,2\% cada, Argentina, 4\%, Peru, 3\%, Uruguai, 2,6\% e Equador, com apenas 1\%. Não foram encontrados dados para o Suriname e Venezuela. Todos os demais referem-se ao ano de 2002 e têm como fonte a UNESCO. (UNESCO Institute for Statistics. 2005. Correspondence on education expenditure. February. Montreal)

A taxa de analfabetismo entre jovens de 15 a 24 anos indica a qualificação da mão de obra que ingressa no mercado de trabalho. Nessa faixa etária, o Brasil apresenta o maior índice de analfabetismo na América do Sul, com 3,9\%. O menor índice pertence à Guiana, que, como se viu anteriormente, investe mais em educação do que seus vizinhos, em termos relativos. O Peru, que investe apenas $3 \%$ do PIB em educação, detinha, juntamente com o Paraguai e Colômbia, o segundo pior índice de analfabetismo nessa faixa etária em 2005, 2,4\%. O Equador vinha em seguida, com $2,1 \%$ de analfabetos jovens.

No campo da saúde, o quadro tem um arranjo novamente diferenciado. Nessa área, a Colômbia apresentou o maior investimento público em relação ao PIB no ano de 2002, 6,7\%. Argentina, com 4,5\%, Guiana, com 4,3\% e Bolívia, com 4,2\%, vinham em seguida. $\mathrm{O}$ Brasil apresentou o mesmo percentual que o Suriname, 3,6\%, e logo abaixo estava o Paraguai, com 3,2\%. Com investimentos públicos em saúde abaixo de $3 \%$ em 2002, estavam Uruguai, com 2,9\%, Chile, $2,6 \%$, Venezuela, $2,3 \%$ e Peru, 2,2\%. O Equador, com 1,7\% do PIB, era o país que menos investiu em saúde na América do Sul em termos percentuais ${ }^{16}$.

$\mathrm{Na}$ mesma linha, outros dados poderiam se trazidos à analise fortalecendo a percepção de que a América do Sul é uma região de países em condições extremamente desiguais. As desigualdades impõem obstáculos à integração, tanto pela definição da agenda em cada um dos países, quanto pelas dificuldades impostas pelas assimetrias na construção das políticas integracionistas.

Com esse quadro, as possibilidades de inserção no mundo global são díspares entre os doze países, e as relações intra-regionais refletem também esse

16 Fonte: PNDU - Human Development Report- 2005. 
desequilíbrio. Os fluxos entre os países sul-americanos sinalizam para algumas ligações bilaterais fortes, mas que não chegam, de modo algum, a formar uma rede de relacionamento multilateral consolidada.

Primeiramente, a relação comercial de cada um dos doze países sul-americanos com seus vizinhos reflete suas estruturas de produção desiguais, graus diferenciados de modernização de suas economias e níveis díspares de competitividade regional e global. Isso implica que a participação relativa de comércio de cada um dos países direcionado aos vizinhos sul-americanos seja bastante diferenciada, embora seja perceptível um aumento desse grau de interação ao longo dos anos.

Observando os dados da CEPAL sobre o comércio dos países da região entre 1990 e 2004, nota-se, em geral, um aumento na participação das importações advindas da América do Sul sobre o total das importações dos países sulamericanos. A exceção é o Brasil que, mesmo com a implantação do Mercosul e com a adoção de medidas de incentivo às importações de países sul-americanos, em 2004 viu a participação das importações advindas da América do Sul cair a um nível menor do que o observado em 1990.

A Venezuela, de outra parte, foi o país que apresentou um acréscimo relativo maior nas importaçõos dos países sul-americanos. De 9,77\% em 1990, as importações com origem no sub-continente representaram 26,49\% em 2004, indicando um aumento de $171 \%$ nessa participação, numa trajetória crescentemente constante. Isso ajuda a explicar, em parte, o aumento da influência venezuelana na região.

O Equador, na mesma linha, aumentou em 121,89\% a participação das importações dos países sul-americanos no total das suas importações. Em seguida, situam-se Paraguai e Chile, países em que o aumento da participação das importaçóes sul-americanas no total das importações representou, respectivamente, $64,04 \%$ e $62,44 \%$. No entanto, esse não é o padrão dos países que compóem o Mercosul, como se poderia pensar. Na Argentina, esse acréscimo foi em torno de $32 \%$, enquanto o Uruguai, por sua vez, não aumentou a participação relativa das compras sul-americanas mais do que 3,52\%.

O padrão de evolução das exportações para a América do Sul de cada um de seus países é mais heterogêneo que o das importações, mesmo que, novamente, observe-se um aumento na participação da América do Sul como destino das exportações de cada um dos países da região. A exceção, nesse aspecto, é o Uruguai, no qual a participação das exportações para os países sul-americanos sobre o total das exportaçōes, em 2004, era 17,22\% menor do que em 1990 - apesar de ter um acréscimo em meados da década de 1990, refletindo o sucesso inicial do Mercosul.

$\mathrm{Na}$ outra ponta, a Colômbia se destaca com um aumento relativo das exportações para a América do Sul da ordem de 143,27\%, passando de 9,06\% em 1990, para 22,04\% em 2004, se bem que com um decréscimo nos primeiros anos do início do século XXI. Equador, Argentina, Bolívia e Venezuela, da mesma forma, aumentaram a parcela de suas exportaçôes destinada à América do Sul em números consideráveis: $62,48 \%, 56,78 \%, 41,31 \%$ e $38,16 \%$, respectivamente. 
O Brasil, por seu turno, aumentou em $88,28 \%$ a parcela das suas exportaçōes destinadas à América do Sul, comparando-se 1990 e 2004. A trajetória mostra um acréscimo considerável na década de 1990, obviamente também reflexo do êxito inicial do Mercosul. As crises de final dos anos noventa e início dos anos 2000, que acentuaram as dificuldades que as políticas cambiais diferentes e desarticuladas representavam, fizeram com que essa participação diminuísse, recuperando-se a partir de 2003, mas ainda sem alcançar os números de 1995 ou 2000.

$\mathrm{O}$ aspecto mais relevante destaca-se, no entanto, ao compararmos os dados dos dois gráficos conjuntamente. Ressaltam-se algumas "situações tipo" que revelam, novamente, uma integração sul-americana desigual e desequilibrada. Em primeiro lugar, o Uruguai é o único país que apresenta queda na participação da América do Sul na sua pauta exportadora ao mesmo tempo em que, comparandose 1990 e 2004, apresenta o menor crescimento - excetuando-se o Brasil, que apresentou um decréscimo - da participação relativa dos produtos advindos da América do Sul no total de suas importações. Ou seja, observando-se apenas as relações comerciais, o Uruguai esteve, nos últimos anos, em realidade, se desarticulando dos seus vizinhos sul-americanos.

Caso oposto é o do Equador, em que não só a participação da América do Sul como destino às suas exportações aumentou $62,48 \%$ no período, passando de $10,42 \%$, em 1990, para 16,93\%, em 2004, como também a participação das importações advindas dos demais 11 países sul-americanos no total das importações equatorianas aumentou 121,89\%. Em 1990, a América do Sul respondia por $17,82 \%$ das importações equatorianas, enquanto em 2004 esse número era de 39,54\%. A integração do Equador com os mercados sul-americanos foi intensa.

O Brasil, por sua vez, apresentou também uma dinâmica singular. Se, por um lado, a participação relativa das importações advindas da América do Sul no total de suas importações diminui, passando de 16,06\% em 1990 para 14,94\% em 2004, a região tem uma importância crescente na sua pauta de exportações, com um crescimento de mais de $88 \%$, passando de $8,62 \%$ para $16,23 \%$. Revela-se aí uma integração severamente desequilibrada, que tem seguramente seus reflexos nos resultados das estratégias de integração regional empreendidas pelo Brasil e no seu relacionamento comercial bilateral com os países da região. Daí também se justifica boa parte das queixas que os parceiros comerciais sul-americanos têm freqüentemente expressado contra o Brasil nos últimos anos.

Em situação inversa à do Brasil está o Chile. O peso da América do Sul como destino das exportações chilenas vem caindo desde 2001, depois de se manter estável entre 1995 e 2000. Comparando 1990 e 2004, o aumento foi pequeno, de apenas $1,06 \%$ (11,28\%, em 1990, e 11,4\%, em 2004). Já a participação da América do Sul nas importaçóes chilenas aumentou $62,44 \%$, passando a responder por $37,72 \%$ do total em 2004, contra 23,22\% de 1990 .

Ademais, a integração comercial da América do Sul, não só desequilibrada e desigual, é pequena. Análise do Banco Mundial, com dados do ano 2000, mostra 
que o comércio intra-regional no Mercosul - 25\% sobre o total exportado, e na Comunidade Andina - 10\% ainda estava bastante aquém do nível de regiōes como a União Européia - 60\%, NAFTA - 55\% e Ásia - 68\%

Indo mais além, ao se analisar as relações comerciais país a país percebem-se grandes eixos bilaterais de comércio que, em si, traduzem a dinâmica regional, sem, no entanto, envolver toda a região numa rede de relacionamento comercial consolidada, crescentemente amarrada. Por esse ângulo, a América do Sul revelase como um conjunto de relaçôes bilaterais tradicionalmente relevantes, mas que ainda não foram capazes de integrar-se para conferir unicidade à região.

Nessa linha, segundo dados da CEPAL, apenas quatro grandes pares comerciais superaram o valor de US\$ 2 bilhōes em 2004. O principal fluxo comercial na América do Sul, obviamente, está entre Brasil e Argentina, somando quase US\$ 13 bilhōes em 2004. Para a Argentina, as exportaçōes destinadas ao Brasil representaram 16,17\% do total de suas exportações. Já para o Brasil, as exportações para seu principal vizinho representaram $7,64 \%$ do total exportado pelo país.

O segundo maior fluxo comercial na América do Sul é entre Argentina e Chile, que superou os US\$ 4,2 bilhōes em 2004. 11,11\% das exportações argentinas foram para o Chile nesse ano, o que significa afirmar que quase $1 / 3 \mathrm{de}$ tudo o que a Argentina exporta destina-se a Brasil e Chile.

A relação comercial entre Brasil e Chile é a terceira maior na região, confirmando que a maior integração sul-americana está, de fato, no Cone Sul. Brasil e Chile tiveram em 2004 um fluxo comercial de quase US\$ 4 bilhões. Em termos percentuais, no entanto, a participação destes países na pauta comercial do seu parceiro não chega a $5 \%$.

A quarta maior relação comercial bilateral na América do Sul é entre Colômbia e Venezuela, apesar das pendências diplomáticas entre os dois países. O fluxo comercial entre eles superou os US\$2,6 bilhôes de dólares em 2004. Essa relação é mais importante para a Colômbia, pois a Venezuela sozinha recebe 9,7\% de suas exportaçôes.

Isso revela, sobretudo, que qualquer iniciativa de integração sul-americana deve considerar as fortes assimetrias entre os países. O Brasil não só é o grande país em extensão territorial como é o pólo irradiador, pelo tamanho da sua economia, do comércio intra-regional. Em contrapartida, como se viu anteriormente, é também o único país que vem diminuindo, da década de $1990 \mathrm{em}$ diante, as suas importações dos países da região, em termos relativos. O desequilíbrio é estrutural na América do Sul.

À parte desse critério quantitativo, algumas outras relaçōes bilaterais merecem destaque pelo grau de relevância para seus parceiros. A primeira delas é a relação bilateral entre Brasil e Bolívia, que superou US\$ 1 bilhão em 2004. As exportações destinadas ao Brasil representaram 31,66\% do valor exportado pela Bolívia nesse ano, assentado, sobretudo, na exportação de gás natural via o gasoduto Brasil-Bolívia, inaugurado no início dos anos 2000. O segundo 
maior destino das exportações bolivianas na América do Sul é a Venezuela, que respondeu por mais de 10\% do valor exportado pela Bolívia em 2004.

As relações comerciais entre Equador e Peru, embora não tenham alcançado o nível de US\$ 1 bilhão em 2004, revelam uma forte ligação bilateral na qual as exportaçóes equatorianas ao Peru representaram 7,81\% do valor total exportado por aquele país. Esse percentual alcançou 10,32\% em 2003, o que, para países que recentemente enfrentaram-se em conflito armado, é bastante significativo.

Outra importante relação bilateral dá-se entre Paraguai e Uruguai, na qual este respondeu, em 2004, por 27,76\% do valor exportado pelo primeiro. Em 2004, o Uruguai foi o primeiro parceiro comercial do Paraguai, surpreendentemente acima de Brasil e Argentina. O Brasil, que respondia por mais de $30 \%$ do valor exportado pelo Paraguai, curiosamente em 2004 recebeu menos de 20\% das exportações paraguaias em termos de valor exportado.

O fluxo de investimento entre o Brasil e os países sul-americanos retrata uma redução na importância da América do Sul como região preferencial de atuação externa. Segundo dados do Banco Central do Brasil, o fluxo de investimentos brasileiros diretos na América do Sul vinha numa trajetória declinante nos primeiros quatro anos do século XXI, período em que essa mensuração vem sendo apurada.

Em 2001, a América do Sul foi o destino de 10,30\% dos investimentos diretos brasileiros, em todas as modalidades - inclui-se empréstimos intercompanhias, demais empréstimos, depósitos e financiamentos. De fato, chega a ser um percentual relevante, tendo em vista que quase $57 \%$ do total dos investimentos diretos brasileiros destinaram-se a apenas três países, todos paraísos fiscais - Ilhas Cayman, Ilhas Virgens e Bahamas.

Todavia, em 2002, a América do Sul representou 7,21\% do total dos investimentos brasileiros no exterior, um decréscimo de cerca de $30 \%$, a despeito de esses terem aumentado 5,3\% nesse ano. Em 2003, essa participação tem uma leve recuperação, representando $8,30 \%$ do total. Já em 2004, caiu para o nível mais baixos dos anos para os quais há disponibilidade de dados, tendo recebido 6,46\% do total. É importante frisar que em 2004 os investimentos externos do Brasil no exterior foram quase $34 \%$ acima do que os declarados no ano 2001 .

Ademais, compondo o cenário de queda de importância da América do Sul nos investimentos externos direitos do Brasil e a diminuição da participação dos países da região nas importações brasileiras, o ingresso de pessoas advindas dos onze países sul-americanos no Brasil também decresceu em termos de participação relativa nos últimos anos. De acordo com os levantamentos feitos pela Embratur e pela Polícia Federal, a América do Sul que em 1993 foi responsável por 68,76\% dos turistas que entraram no Brasil, em 2005 emanou apenas 37,63\% dos estrangeiros que entraram no país, consolidando-se, desde 2003, na segunda posição, atrás da Europa, que em 2005 respondeu por 38,62\% dos estrangeiros que entraram no Brasil. A Argentina, no entanto, continua sendo o país maior emissor de turistas para o Brasil. Em 2001, 28,80\% dos estrangeiros que entraram 
no Brasil eram argentinos. De 2002 em diante, esse percentual fica em torno dos 19\%, ainda o suficiente para garantir a primeira posição para a Argentina. De todo modo, essa queda explica uma grande parcela da diminuição da importância relativa da América do Sul.

Observando em conjunto o comportamento de outros sete países sulamericanos que constam na lista dos vinte principais países emissores de turistas para o Brasil, percebe-se um posicionamento estável do bloco. Uruguai, Paraguai, Chile, Bolívia, Peru, Venezuela e Colômbia respondiam, em 2001, por 19,61\% dos turistas que visitaram o Brasil naquele ano. Em 2005, esse número ficava em 18,38\%. Em suma, a densidade das relações sociais, no que tange ao fluxo de pessoas, não tem aumentado entre os países sul-americanos e o Brasil. Ao contrário, em parte devido à crise econômica e social enfrentada pelo nosso maior vizinho, essa relação tem diminuído.

\section{Conclusão}

As regiōes são produtos de construções sociais, produzidas e reproduzidas por discursos e práticas sócio-econômicas e políticas. Não são, portanto, objetos atemporais, fixos no tempo e espaço. São construções dinâmicas, que se movimentam a partir das relações entre territórios e comunidades diferentes.

Nessa linha, a América do Sul, para além dos seus contornos geofísicos, ainda está em construção. Como se viu, a proximidade geográfica não significou, ao longo da história, uma articulação robusta entre os países da região.

Certamente, o espaço sul-americano está mais articulado no início do século XXI do que estava há cem anos atrás. No entanto, os dados apresentados revelam que a dinâmica dos fluxos intra-regionais ainda não apresenta um comportamento que permita aferir que tenha alcançado o nível que suas potencialidades sugeririam.

Os desequilíbrios e desigualdades observados no interior de seus países extrapolam para o nível intra-regional. Com essa plataforma, a definição de objetivos comuns para a região é um exercício bastante complexo. Com tamanha heterogeneidade, fica inclusive mais complicado a afirmação de uma identidade regional própria. No entanto, a própria dinâmica da integração regional pode suscitar processos de socialização que incluem a redefinição de identidades, o que poderia implicar também a remodelagem dos cálculos para aferição de custos e benefícios, perdas e ganhos, envolvidos no processo.

Nessa linha, antes de condenar a estratégia brasileira de definição de um horizonte sul-americano para sua política externa, é importante ter em mente o papel dos Estados no esforço de construção da região, tanto na área econômica, quanto nas áreas social, cultural e científica-tecnológica. Os Estados devem reforçar seu papel de organizadores do território, atentando para a integração aos fluxos regionais e globais, que condicionam a inserção das sociedades na economia mundializada. 
A integração das infra-estruturas é essencial nessa estratégia. Essa etapa não deve ser encarada como um fim em si mesma, mas um meio fulcral para alavancar e dinamizar um processo de construção de redes de interação regional que, coesas, têm mais condições de se lançar ao globo.

Delimitado o horizonte regional do Brasil, o desafio passa a ser a própria construção da América do Sul enquanto região. Uma hercúlea tarefa que um país, a despeito do seu tamanho e importância no concerto regional, não consegue implementar sozinho. Construir e integrar a América do Sul, antes de tudo, tem que ser um desejo de todos os seus membros.

Recebido em 5 de janeiro de 2007 Aprovado em 15 de abril de 2007

\section{Resumo}

No artigo se procura demonstrar que o horizonte regional do Brasil delimitou-se, nos últimos anos, pela América do Sul, tendo se respaldado por uma séria de ações que operacionalizam a retórica diplomática e vão além da esfera econômico-comercial. A pesquisa aponta, entretanto, que a América do Sul ainda é uma região em construção e iniciativas como a do Brasil podem fortalecer esse processo.

\section{Abstract}

This article seeks to show that South America characterizes the actual Brazil's regional horizon. The Brazil's foreign policy implements several actions that lend a practical face to the diplomatic rhetorical and surpass the economic-commercial sphere. Therefore, the research points that South America is still a region in construction, and Estates' initiatives, as Brazilian's, can deeply contribute to this process.

Palavras-chave: América do Sul, Integração Regional, Política Externa Brasileira. Key words: South America, Regional Integration, Brazilian Foreign Policy. 